\title{
Breaking and Making Identities: Transformations of Ceramic Repertoires in Early Colonial Hispaniola
}

\author{
Marlieke Ernst and Corinne L. Hofman
}

The first interactions between Spaniards and the peoples of the New World on the island of Hispaniola (presently Haiti and the Dominican Republic) set the stage for the course of colonization in the rest of the Americas (Hofman et al. 2018). Outcomes of the first encounters included miscommunication, misunderstanding, conflict, enslavement, and a range of other intercultural interactions. Intermarriages between Spanish men and Amerindian women, slavery, the taking of concubines, as well as exchange of goods and food items occurred on a regular basis (Deagan 1988, 2004; Sauer 1966; Valcárcel Rojas et al. 2013). These exchanges resulted in a process of transculturation; ${ }^{1}$ a creative, ongoing, process of appropriation, revision, and survival both in social and material dimensions (Ortiz [1940] 1995). Transculturation did not only occur between the indigenous peoples of Hispaniola and the Spanish. In 1503, the Spanish obtained legal justification to move indigenous peoples across the islands. Indigenous slavery was thereby officially sanctioned by the Crown (Anderson-Córdova 1990, 2017; Hofman et al. 2018; Rivera-Pagán 2003). One of the destinations of these indigenous enslaved laborers was Hispaniola (Anderson-Cordova 1990; Rivera-Pagán 2003; Sued Badillo 2001). By 1505, enslaved Amerindians were supplemented by enslaved Africans (Rivera-Pagán 2003; Olsen Bogaert et al. 2011a). Through time, increasingly more Africans

1 Colonialism was typically associated with domination, ignoring competition, and especially alliance. However, a more nuanced understanding of colonial interaction is achieved when considering postcolonial concepts of agency and identity (Valcárcel Rojas 2012). It is here that models of transculturation (Ortiz [1940] 1995), ethnogenesis (Deagan 1996, 1998; Voss 2008), creolization (Hannerz 1987), and hybridity and hybridization (Bhabha 1994; van Dommelen 1997) have become prominent in archaeology and studies of colonialism. These models provide interpretive frameworks for the sociocultural factors that led to the emergence of new identities and cultural expressions. Transculturation was retained as a concept here as it was developed within a Caribbean setting as it covers the colonial process as a whole, and includes the transformative effects that all parties experienced as a consequence of the mutual influences on each other.

(C) MARLIEKE ERNST AND CORINNE L. HOFMAN, 2019 | DOI:10.1163/9789004273689_007

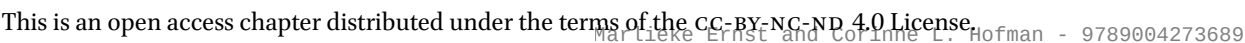




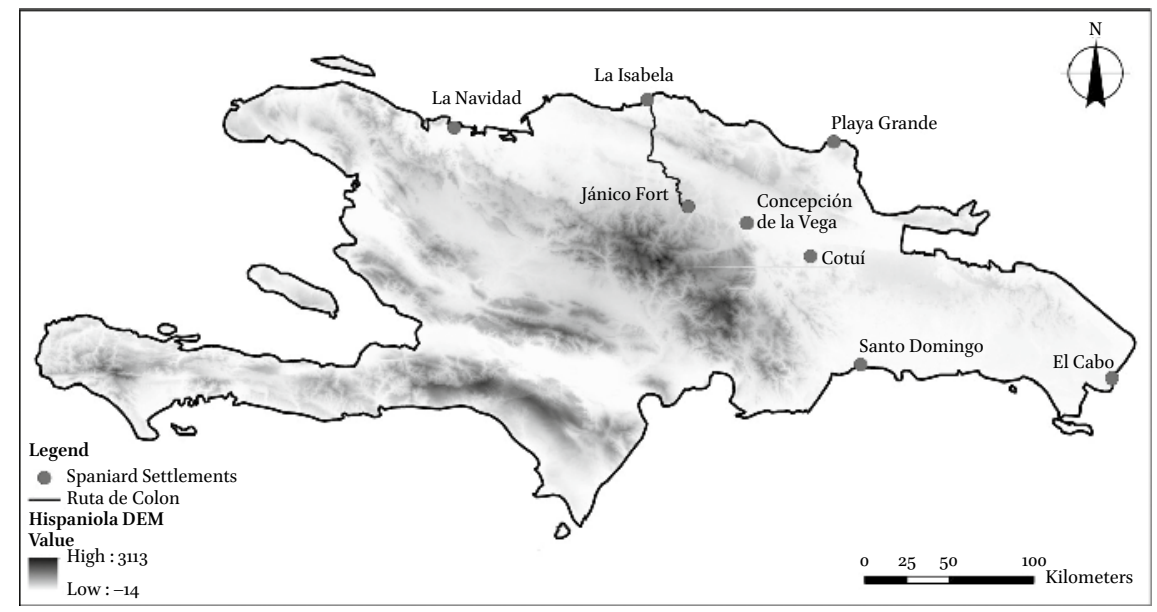

FIGURE 6.1 Map of Hispaniola

MAP BY EDUARDO HERRERA MALATESTA. DEM BASED ON AN ASTER GDEM IMAGE: HTTPS://GDEX.CR.USGS.gOV/GDEX/. ASTER GDEM IS A PRODUCT OF NASA AND METI

were imported resulting in new blends of enslaved Amerindian and African communities within the framework of Spanish colonialism.

In this chapter, we examine the material implications of these blended communities through (1) the incorporation of European earthenwares in the indigenous settlements of El Cabo and Playa Grande, in southeastern and northern Dominican Republic, respectively, and (2) the reflection of Amerindian, Spanish, and African interactions in the ceramic manufacturing traditions in the early Spanish colonial sites of Cotuí and Concepción de la Vega, in central Dominican Republic (Figure 6.1).

\section{$2 \quad$ Methodology}

This chapter works with the assumption that people and objects maintain dialectic relationships. Objects are seen as active agents in creating social relationships (Giddens 1979; Gosden 2006; Gosselain 2000; Hoskins 2006).

A low-tech ceramic analysis ${ }^{2}$ was carried out on four assemblages from the Dominican Republic. This analysis addressed stylistic, morphological, and technological features of the ceramics. To study the incorporation of

2 A "low-tech" (or "no-tech") analysis can be considered of simple techniques and tools (10x hand lens, a simple microscope, and pliers). This way you can rapidly and easily study large collections of ceramic materials in the field. As these techniques are non-destructive, it is 
European earthenwares at the indigenous sites of El Cabo and Playa Grande, a typological identification of the European sherds was conducted based on vessel shapes and decoration modes. The low-tech fabric analysis was aimed at documenting the texture of the clay bodies and inclusions in order to establish whether sherds belonged to one or more vessels or if they were traded as individual sherds. The latter possibility is suggested by early historical accounts stating that sherds were used as trade objects (Eliot 2001). Establishing the provenance of the European ceramics was not the focus of this study, therefore mineralogical characterization of these sherds was not carried out. Microscopic analysis (10X hand-held and $20 \mathrm{X}$ Leica DM3oo lens) was performed to identify intentional modifications of the European sherds. Abrasion and perforation are ways to intentionally modify sherds to transform them into other objects. Modifications of European objects by indigenous peoples have been documented elsewhere; e.g., abraded sherds used as miniature pot lids, spindle whorls, game pieces or valuables, and needles of a navigator's compass converted into pendants (Knight 2010; Roe and Ortiz 2011; Torres and Carlson 2011).

Spatial analyses were performed to identify distribution patterns, contexts, and relationships between the European and Amerindian ceramics in El Cabo and Playa Grande. Ceramic spatial distributions were important to study potential differential treatment of the European and Amerindian wares before and after disposal. In El Cabo, it was possible to study post-depositional processes to determine if the European and Amerindian ceramics shared similar life cycles before and after deposition. In particular, it was possible to address variation in and consequences of trampling rates between the two wares. For this purpose, $5^{6}$ Chicoid $^{3}$ sherds were selected for comparison with 45 European ceramics. Under similar conditions, we would expect sherds of both wares to break in the same manner if they were of the same quality (Nielsen 1991; Schiffer 1983). Sherd hardness is an important variable in terms of trampling damage; soft materials are more readily damaged than hard materials. Sherd hardness was measured on the Moh's scale (Rice 1987). Due to different excavation strategies and limited access to the materials of Playa Grande it was not possible to perform the exact same analysis as was done for the sherds of El Cabo.

The non-European ceramics of the Spanish colonial sites of Concepción de la Vega and Cotuí were classified by vessel shape and wall profile, lip shape and rim profile, wall thickness, orifice diameter and percentage of rim present,

also a good alternative to study materials in museums or with other restrictions when it comes to technological or compositional analysis (Rice 1987).

3 Chicoid is a ceramic series characterized by incision and punctuation as well as zoomorphic and anthropomorphic modeled appliqués as described by Rouse 1992. 
decorations, vessel interior and exterior Munsell colors, firing atmosphere, surface finish, and the presence of slips, or appendages (Hofman 1993).

Manufacturing techniques of the locally-made ceramics were studied according to the chaine opératoire approach. This approach enables the study of the manufacture process of material culture, and reveals the technical choices selected by the potters (Bar-Yosef and van Peer 2009; Farbstein 2011; Lemmonier 1986, 1992, 2002; Leroi-Gourhan 1964; O'Shepard 1963; Roux 2016). The chaîne opératoire reflects on the potters' various technical traditions, networks, and strategies (Leroi-Gourhan 1964; Roux 2016). Manufacturing processes are not static and may change in response to a variety of internal and external factors, including invasion and conquest and innovation and inspiration through new cultural forms. Invaders or in-marrying partners may bring new objects or novel ideas that result in changes to established manufacturing techniques, which in turn may spread through socioeconomic networks or human dispersal (Gosselain 2000; Rice 1984). It is probable that interactions between Amerindians, Spaniards, and Africans resulted in changes in the chaîne opératoire. Some steps in the chaîne opératoire of ceramics are more prone to change while others are more conservative and difficult for the potter to change. Ceramic ethnographic studies show that the conceptualization and forming methods of vessels are highly conservative, while it is easier to vary the raw materials, vessel shape, surface finishing, decoration, and firing techniques (Balfet 1984; Gosselain 2000; Hernández Sánchez 2011; van der Leeuw 1993; Orton et al. 2005; Rice 1984). The techniques used are determined by the potter's conceptualization of pottery technologies. These technologies involve motor skills and specialized gestures deeply rooted within the learned behaviors of the potters (Löbert 1984; Rice 1987; Skibo and Schiffer 2008). This pottery technology is what potters express as essential characteristics of their wares, especially in terms of how they think pots should be made and what they look like.

Low-tech analysis of the chaîne opératoire of the non-European sherds of La Vega and Cotuí focused on forming and firing techniques (Figure 6.2). Forming techniques were studied by looking for traces of coiling or wheel throwing on the surface and broken edges of the sherds. The study of firing techniques focused on the firing atmosphere and sherd hardness (Rice 1987). The presence of stone tools for the surface finishing during ceramic manufacture and the recovery of a potter's wheel in Concepción de la Vega indicate that at least some ceramics were made on site. Objectives of the analysis were to identify choices selected in the manufacture of non-European ceramics produced at Cotuí and Concepción de la Vega and to compare them with precolonial manufacturing techniques in Hispaniola to detect continuities and changes. 


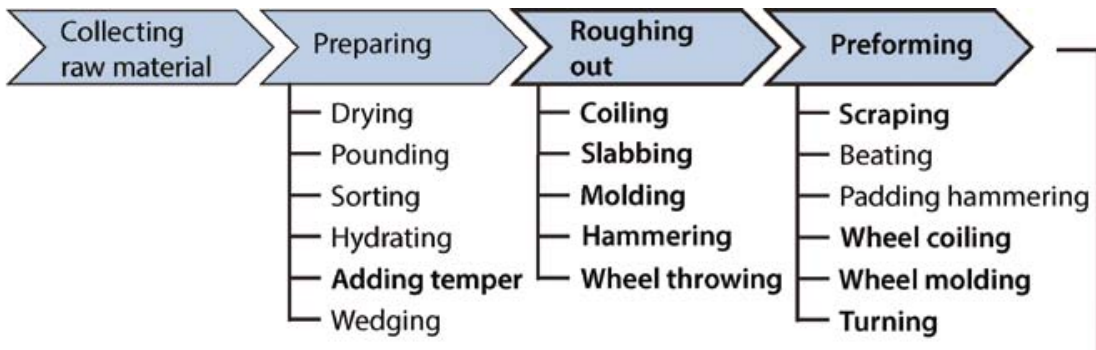

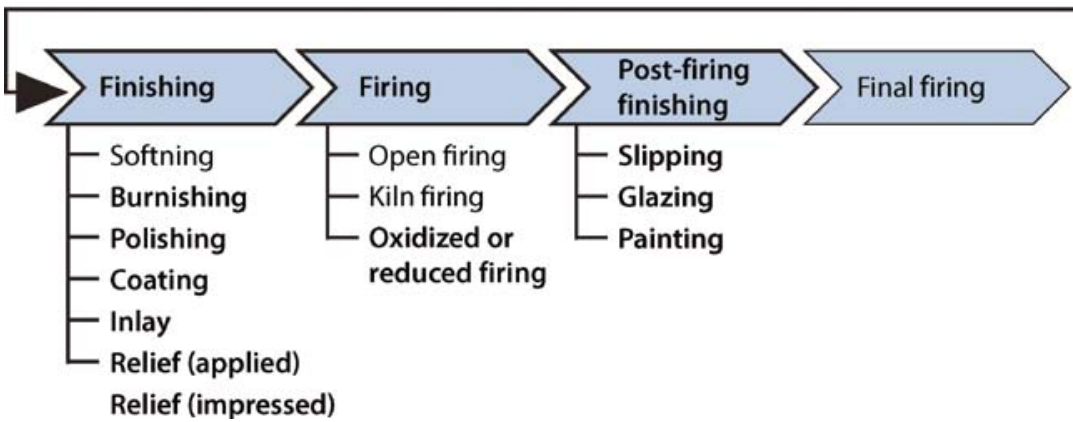

FIGURE 6.2 The chaine opératoire of ceramics. In bold are the steps for which this project has data ORIGINAL DESIGN BY MARLIEKE ERNST AND FIGURE BY MENNO L.P. HOOGLAND

\section{1} El Cabo

The archaeological site of El Cabo is situated in the Higüey region on the southeastern coast of the Dominican Republic in the Altagracia Province. Excavation of the site took place between 2005 and 2008 by a team from Leiden University, in collaboration with the Museo del Hombre Dominicano, under the direction of Menno Hoogland and Corinne Hofman (Hofman et al. 2008; Samson 2010). Radiocarbon samples provided a range of dates between the seventh and early sixteenth centuries AD.

The material assemblage associated with the later component of the site consists primarily of Chicoid ceramics and associated materials (Hofman et al. 2008; Samson 2010). In specific areas of the site materials were mixed with early European colonial materials, including 100 earthenware pieces, five glass beads, a few fragments of glass, animal bones, and fragments of unidentifiable iron objects (Ernst and Hofman 2015; for distribution map of the European material see Valcárcel Rojas et al. 2013) (Figure 6.3). Forty-five European sherds 


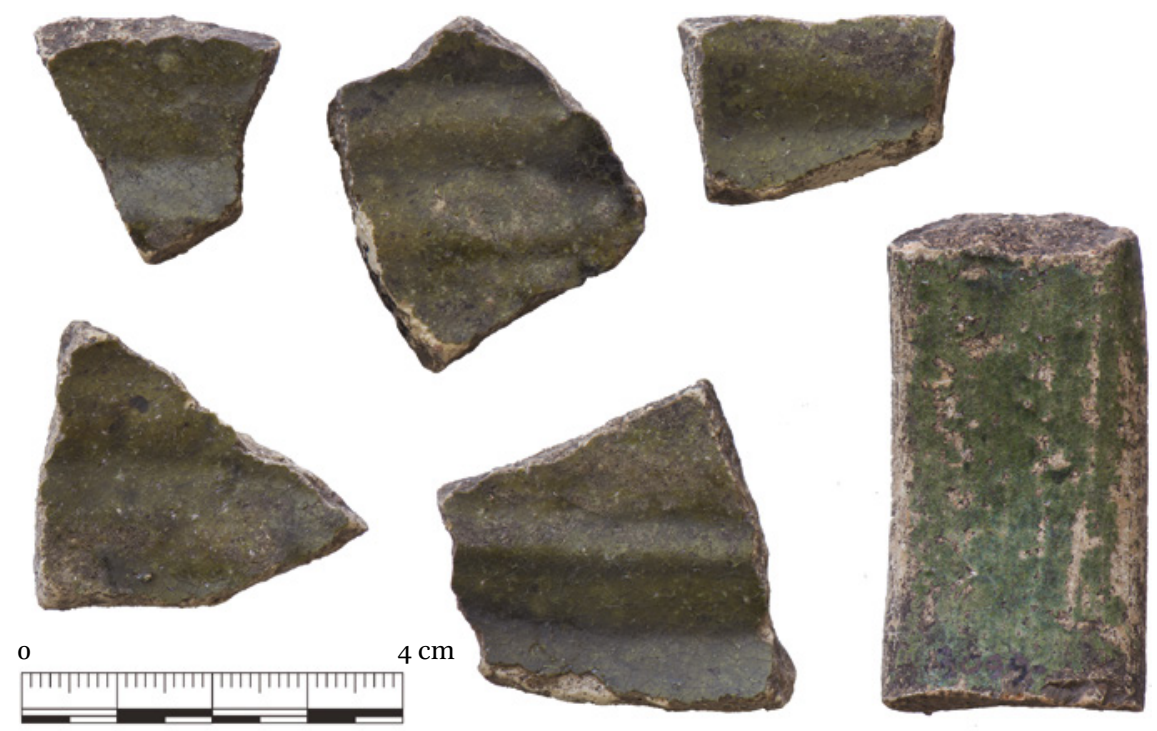

FIGURE 6.3 Olive jar sherds from El Cabo, Dominican Republic PHOTO BY MENNO L.P. HOOGLAND

were selected for analysis: 4 rim sherds, 1 complete handle, 3 handle fragments, and 37 vessel wall fragments. The handle was identified as a vertical handle (French 2005, 25). Five sherds were recognized as pieces of plates and the other 40 sherds were portions of an independent restricted vessel with a composite contour. Most sherds were green tin-glazed, and five were decorated with a white/gray glaze. The green tin-glazed sherds were from an olive jar that could be identified as an early style jar (AD 1500-1570) based on the handle type. The rims were identified as a Type A1 Rim according to Goggin's (1960) system. The white-glazed sherds are most likely Columbia Plain sherds from a plate. The low-tech fabric analysis confirmed that all 45 sherds came from only two vessels, one olive jar, and one Columbia Plain plate. Whether the ceramics ended up at El Cabo as whole pots or as broken pieces is not clear. Microscopic analysis of the surface and the plane of the cracks of the sherds showed that none were abraded or otherwise intentionally modified, suggesting that individual sherds were not re-used post-breakage.

All sherds were recovered from a small area in the main excavation unit. This area is characterized by considerable sweeping accumulations, with possible incidences of primary context finds. The deposits in the unit were shallow, suggesting that they do not represent the main or final dumping areas of the site (Samson 2010). The distribution of the colonial materials can be 
linked directly to one of the house trajectories in the habitation area. The material was clustered at the back of the final structure in the house trajectory, dated to the early sixteenth century (end date AD 1502). This house trajectory is associated with some of the most elaborate finds in the excavations. The colonial materials were found together with Chicoid ceramics, a large stone threepointer (or trigonolith), and a small shell mask (guaiza). The exceptional combination of these artifacts was interpreted as belonging to the residence of an elite member(s) of the El Cabo community (Samson 2010). It appears that the colonial materials exhibit a clear distribution pattern within the disposal area (in contrast to the indigenous ceramics). The olive jar was placed at the center of the deposit and flanked by two pieces of Columbia Plain. The European beads and the ornamental glass fragment were located east of the olive jar. They appear to be small, one time (not reentered) deposits, referred to as "time capsules" (Samson 2010). The distribution pattern could indicate a ritual disposal (see also Fontijn 2002). However, it can also mean that the colonial materials were not of use anymore, lost their value, and were thrown away at different times (Samson 2010; see also Keehnen this volume on En Bas Saline).

Based on European artifact frequency, distribution, and limited early Spanish presence in the area, El Cabo has been interpreted as a contact site, whereby European materials are poorly represented indicating short or indirect interactions (Ernst and Hofman 2015; Hofman et al. 2014; Samson 2010; Valcárcel Rojas et al. 2013). The finding of European materials reflects a short period during which Spanish objects were incorporated into the local material culture and indigenous practices (Samson 2010; Valcárcel Rojas et al. 2013). The close association of European and indigenous items suggests an acceptance and integration of these foreign objects by the local community during the early colonial period (Hofman et al. 2014; Valcárcel Rojas et al. 2013).

\subsection{Playa Grande}

The Playa Grande site is situated in the town of Rio San Juan, on the north coast of the Dominican Republic. When the Spanish arrived, the community belonged to the region of Cuhabo in the province of Hyabo and was tribute to the cacicazgo of Magua, under the leadership of the cacique Guarionex (López Belando 2013; Mártir Angleria 1964). Archaeological research at the site has been undertaken since 1978 and extensive excavations took place between November 2011 and April 2012, led by Adolfo López, delegated by the Museo del Hombre Dominicano and the Instituto de Investigaciones Antropológicas de la Universidad Autónoma de Santo Domingo (López Belando 2012, 2013; Olsen Bogaert 2004). The site was continuously occupied between the eighth and seventeenth centuries AD (López Belando 2012, 2013). Currently it is not 
possible to link the most recent radiocarbon date of ca. $\mathrm{AD} 1680$ to the indigenous component of the site. The material record shows that the site was still in use after the early colonial period. Later stages are, until now, not likely to correspond to indigenous occupations on the island. Four spatial areas were identified in the indigenous site: a habitation area, a burial area, an agricultural zone, and a sweeping area (López Belando 2013).

Material culture associated with Playa Grande mainly consists of Ostionoid, Meillacoid, ${ }^{4}$ and Chicoid ceramics. Many tools were recovered, manufactured from different materials, including jadeite and flint (Knippenberg 2012). The percentage of Ostionoid, Meillacoid, and Chicoid ceramics found in the different strata increases and decreases significantly as the settlement develops. The initial occupation is associated with a majority of Meillacoid, some Ostionoid, and very little Chicoid ceramics. By the final occupation, the percentages of Meillacoid and Chicoid ceramics were almost identical ( $37 \%$ each), but still some Ostionoid ceramics were present (López Belando 2012). In addition, Spanish materials were recovered from the site including a 1505 maravedí coin (minted in Seville), horseshoes, bronze buckles, iron nails, an iron knife, fragments of glass, a blueish glass bead, and fragments of European glazed ceramics (López Belando 2013).

In total, 122 European sherds were recovered, however, only 77 are considered to be from the initial encounter period. The remaining sherds were found near the surface, including probable eighteenth- and nineteenth-century ceramics believed to have washed ashore from shipwrecks off the Playa Grande coast (López Belando 2012). Initial identification of the European sherds was based on the type of glaze, as sherd size and the almost lack of rims did not allow for a further identification. Six glaze types are present in the assemblage. Most sherds were green tin-glazed, followed by glazes of green with white, white, white with blue and purple, white with blue and brown, and brown. The green-glazed ceramics were from olive jar vessels, the base shape did not allow for a more specific identification within the olive jar typology. One of the green-glazed sherds differed from the others by paste and thickness, allowing a possible identification as Green Bacin/Green Lebrillo (Deagan 1987). The one rim present was glazed green on the outside and white on the inside and top, possibly from a jar. The white-glazed ceramic belongs to the Columbia Plain majolica group. The plates and bowls glazed white with blue and purple are typical of Isabela Polychrome majolica. The white with blue and brown belong to the cuerda seca ceramics and the brown-glazed to the melado style (Deagan 1987).

4 Ostionoid and Meillacoid ceramic series as described by Rouse 1992. 
One of the Isabela Polychrome sherds shows signs of reworking. The edges were sanded producing a circular form with a diameter of $3 \mathrm{~cm}$. From other areas in the Caribbean we know that colonial sherds were sometimes modified into spindle whorls (Torres and Carlson 2014), potlids (Roe and Montañez 2014), game pieces (Roe and Montañez 2014), or buttons (Deagan 1999). The size of this sherd suggests that it is was most likely not abraded for functional reasons.

At Playa Grande the European ceramics seem to occur throughout the settlement, perhaps reflecting an easy access to the materials by the indigenousinhabitants through trade and exchange, both through lines of indigenous interactions as well as intercultural contact between indigenous peoples and Spaniards.

The region of Cuhabo experienced far more Spanish influence than El Cabo did. This region paid tribute to Concepción de la Vega, and Spaniards traveled this area a lot more. The region is situated in the north of the island and was subjected to many initial Spanish explorations as well as established tribute systems (Las Casas [1527] 1974; López Belando 2012; Mártir Angleria 1964; Veloz Maggiolo and Ortega 1980). It is therefore likely that the European ceramics present in the site are a result of direct interactions between Amerindians and Spaniards.

Indigenous Pottery in Early Spanish Sites

\subsection{Concepción de la Vega}

The colonial town of Concepción de la Vega is one of the most important archaeological sites for the early colonial period of the island. Situated in the Cibao Valley, it played an important role in suppressing Amerindian resistance. Concepción de la Vega consisted of a military fort, a monastery, and a residential town in which many economic activities took place. The economy of the town included gold minting, sugar production, and cattle herding. The first fort at La Vega was founded in 1494 in the territory of cacique Guarionex, possibly near the town where the cacique lived. Due to increasing resistance to the Spanish by Guarionex's people, La Vega was abandoned by 1498. A new fort was built in 1512 and was in use until 1562 when it was destroyed by an earthquake (Cohen 1997; Deagan 1999; Kulstad 2008; Shephard 1997). The current research focuses on the second fort that was excavated between 1976 and 1996, under the direction of José González and a team from the University of Florida and the Florida Museum of Natural History (Cohen 1997; Deagan 1999).

The assemblage consists of a mix of Spanish, Amerindian, and transcultural artifacts. The great abundance of material culture indicates wealth within the community, represented by the high percentage of Spanish imported ceramics 
(both utilitarian and table wares) and the many elaborate glass and metal artifacts (Deagan 2002; Kulstad 2008). The discovery of a potter's wheel (Card 2007; Ortega and Fondeur 1978) suggests that some wheel-thrown ceramics were made locally, possibly to somewhat maintain an Iberian lifestyle.

The non-European ceramics of La Vega reveal some continuation in the production and use of precolonial Chicoid and Meillacoid pottery during the contact period, including applications of adornos (modeled clay applications under the vessel's rim often depicting zoomorphic or anthropomorphic figures). Other continuities in the production of Amerindian ceramics included methods of vessel forming, selection of clays and tempers, and vessel shapes and wall thicknesses.

However, some major changes from the precolonial record were recorded as well; vessel conceptualization, vessel shape, pre-firing decorations, surface treatment, and use show new introductions. There are clear traces of the introduction of the potter's wheel and some new raw materials used as temper.

At La Vega, new vessel shapes emerged resembling Spanish (plate, jars, and jugs) and African (olla) shapes. The most striking forms are those that do not resemble only precolonial Hispaniolan, European, or African shapes and decorations, and have been labeled as transcultural ceramics (Figure 6.4). Transcultural ceramics show possible influences from Europe, elsewhere in the
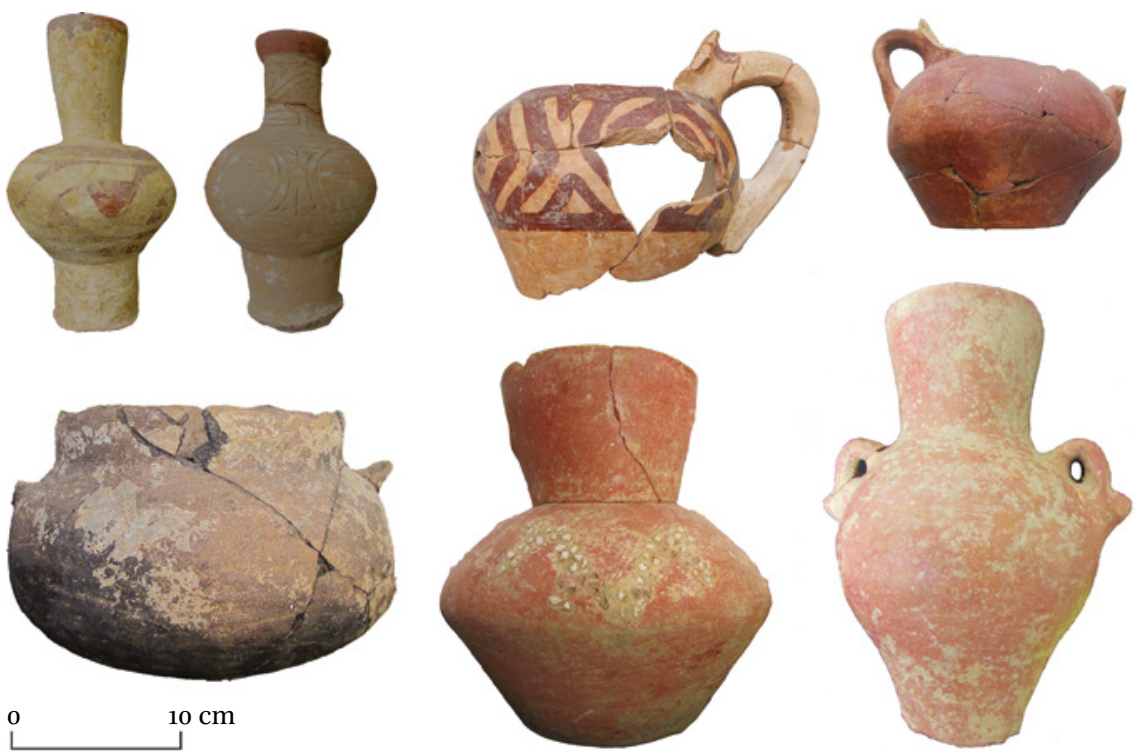

FIGURE 6.4 New forms and decorations showing Amerindian-African and European intercultural dynamics from Concepción de la Vega, Dominican Republic PHOTOS BY MARLIEKE ERNST AND FIGURE BY MENNO L.P. HOOGLAND 
Caribbean, Central and South-America, and/or Africa. Vessels are often red- or white-slipped, or some combination, with elaborate designs. Occasionally, the slipped decoration is combined with fine-line incisions or applications, and more seldom with small pieces of quartz impressed in the clay. Coiling remains the most ubiquitous forming technique, however, the use of the potter's wheel is evident within the non-European ceramics.

At La Vega, substantial amounts of Chicoid adornos were uncovered. However, most of the modeled appliqués resemble a geometric modeling similar to a more stylized form of a Chicoid frog adorno. This stylized form might correspond to the decrease of Amerindian decorative forms in the ceramics. Pastes, wall thicknesses, and vessel shapes, are similar to the precolonial ceramics. However, they are less decorated than before the conquest, showing a decrease in the number of incised vessels. An exception to this is the presence of ceramics decorated with a multi-banded pattern of very fine lines, created by dragging a comb-like tool over the surface (Figure 6.5). These multi-banded, intersecting, wavy patterns are common decorations in West and Central Africa. Variations of these designs commonly adorn ceramics, pipe bowls, circular divination boards, and carved wooden doors (DeCorse and Hauser 2003; Ernst 2016; Ogundiran 2007; Schreg 2010; Weaver 2015). The comb-dragged, multibanded patterns at La Vega occur on the vessel's wall, the rim, and occasionally on the inside of the vessel's base. The rims of this type not only bear incisions, but are also decorated with a pattern created by finger pinching, which is considered to be both an Amerindian as well as an African decorative technique (Weaver 2015). From these rims, it is evident that vessels were very large, possibly associated with sugar production that was introduced to the Caribbean at La Vega (Moya-Pons 1978). Traces of manufacturing techniques show that

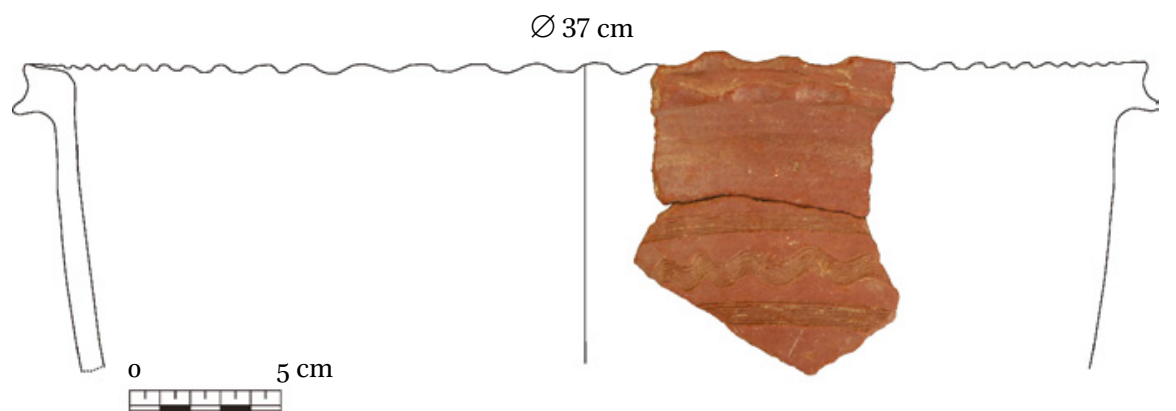

FIGURE 6.5 Pottery sherd from La Vega with a multi-banded pattern of fine lines, created by dragging a comb-like tool over the surface DRAWING BY MARLIEKE ERNST AND FIGURE BY MENNO L.P. HOOGLAND 
these vessels were made on the potter's wheel. Perhaps this type of ceramic shows the adaption of the potter's wheel by African potters. However, Spanish Moorish influence should not be excluded.

\subsection{Cotui, an Early Colonial Mining Camp}

Site 11 in the Cotuí region is also known as the colonial mining camp of the first gold mine exploited by the Europeans in the New World. Gold was obtained by the colonizers at Cotuí by at least 1505, when Fray Nicolás de Ovando sent an expedition to manage the mines in the area. The gold of Cotuí was minted at Concepción de la Vega. Excavations at the site were conducted between July and December 2010 under the direction of Harold Olsen Bogaert and the Museo del Hombre Dominicano. Site 11 is comprised of two buildings: the church and the mining camp (consisting of three plots of stone buildings). In addition, eight postholes were identified. The area contained many traces of firing, and possibly represents a perishable booth or place to prepare food for the miners, or a place for the processing or removing of metals during the sixteenth century (Olsen Bogaert et al. 2011a, 2011b).

Artifacts from the site included both Spanish and Amerindian materials. Most of the artifacts were ceramics. Various stone tools were recovered, including some probably used in the making of pottery, indicating on-site pottery production. Many luxury metal and glass objects reflect the importance of the mine to the Spaniards (Olsen Bogaert et al. 2011a, 2011b). In total, $59.05 \mathrm{~kg}$ of ceramics were analyzed, out of which $21.66 \mathrm{~kg}$ were identified as non-European (Ernst 2016). The area with the highest concentration of non-European ceramics corresponds with the eight postholes, although non-European sherds were also found across much of the site with the exception of the colonial structures (Olsen Bogaert et al. 2011a, 2011b). Most of the non-European ceramics were recovered from the $12-25$ and $25-46 \mathrm{~cm}$ deep strata (Ernst 2016). Deeper layers produced elevated percentages of European ceramics dating to the fifteenth and sixteenth centuries. This stratigraphic arrangement suggests a process whereby the initial widespread use of imported European earthenwares was gradually replaced by locally produced pottery (Olsen Bogaert et al. 2011a).

The Cotuí non-European ceramic assemblage shows that vessel conceptualization, surface treatment, pre-firing decorations, and use changed during the transculturation process after European colonization. In some cases, changes were documented in raw material collection, vessel forming, and firing. Vessel shape and decorations were especially subject to change. None of the elaborate vessel shapes and decorations previously present in Meillacoid and Chicoid ceramics were present in the Cotuí assemblage. The only observed continuities 
were the raw materials, paste preparation, coiling forming techniques, surface treatment, and the use of applications on the vessel surface (Ernst 2016; Ting et al. 2018).

Vessel shapes unknown to precolonial Hispaniola were introduced resembling both African and Spanish vessels (the African olla and the Spanish loza común bacin). Nonetheless, these vessels were still made with the traditional coiling technique characteristic of both traditional Amerindian and African ceramic manufacturing techniques. The addition of appliqués directly under the vessel's rim also coincides with Amerindian ceramic manufacture. Nine traditional adornos were found, which is remarkably low when compared to their occurrence in precolonial assemblages in Hispaniola. The majority of the appliqués, however, resemble the same geometric modeling as shown in La Vega. Pastes, wall thicknesses, and vessel shapes are similar to the precolonial ceramics. Vessel decorations are plainer than precolonial versions. About 30 sherds resemble the transcultural ceramics from La Vega, and were probably manufactured at Concepción de la Vega. This might reflect the historically known connection between Concepción de la Vega and Cotuí (Deagan and Cruxent 2002). The impressed decorations and the addition of a yellowish slip on three red paste sherds are consistent with and provide evidence for West African continuity (Ernst 2016). Other expressions of transculturation within the Cotuí assemblage include the presence of sherds with the same multibanded comb-dragged pattern. The manufacturing technique consists of coiling finished on the potter's wheel. The sherds are similar in style as the ones in Concepción de la Vega. Since only four sherds of this type were recovered from Cotuí, it is at this stage hard to tell if they were made at Cotuí. It might be suggested that their presence is a result of interactions between Cotui and Concepción de la Vega.

The last indicator of change is the clay pipe found in the site. Clay tobacco pipes have been found in the precolonial Caribbean, however not of this type. The shape of this pipe suggests an African introduction without a clay stem where a piece of reed or a straw was inserted. The impressed decorations also resemble African traditions, but a similar placement of decorations is also found on European pipes (Ernst 2016; Sudbury and Gerth 2014).

Following the first encounters between Amerindians and Spanish in the Greater Antilles, material culture, notably ceramics, have been exchanged between the two societies. Many types of European ceramics have been recovered from 
indigenous sites throughout Hispaniola. Likewise, Amerindian ceramics have been found in Spanish sites. The functions of the ceramics in their respective settlement's context differ greatly. This is partially due to difference in the nature of interactions in indigenous towns and those in Spanish ones.

However, the nature of contact between the indigenous inhabitants and the Spaniards was also different in Playa Grande than in El Cabo. In the sixteenth century, the closest Spanish settlement to El Cabo was about 200 kilometers away. The first encounters in the region of El Cabo were rather late in the colonization of the island and mainly due to Spanish trade of manioc between Santo Domingo and Isla Saona (Samson 2010). On this basis, as well as the characterization of the European materials, it is suggested that the colonial assemblage of El Cabo is the result of a single instance of direct trade between the Spanish and the inhabitants of El Cabo, or more likely the result of indirect (down-the-line) trade within local exchange networks (Hofman et al. 2014; Samson 2010; Valcárcel Rojas et al. 2013). The nature of the discard patterns indicates that there was a shift in value from regular Spanish ceramic vessels (or even sherds) to those ceramics being valuable items for the indigenous communities. In contrast, Playa Grande was situated in a region where Spanish presence was stronger as many of the initial navigations by the Spanish occurred along the northern coast (Deagan and Cruxent 2002; Sauer 1966). The amount and diversity of European earthenwares found throughout the site suggests that direct contact occurred more often in Playa Grande than El Cabo. By the time the Spaniards arrived, Playa Grande belonged to the cacicazgo of Magua, under the leadership of cacique Guarionex who was known to pay tribute to the fort of La Vega (Sauer 1966). It is not known if inhabitants from Playa Grande were put to work in the Spanish towns. However, the importance of the region for the Spanish meant a substantial presence of Europeans in the vicinity of Playa Grande. The presence of European earthenwares may reflect direct trade between the indigenous people of Playa Grande and the Spanish, although down-the-line exchange cannot be excluded. Not enough is known regarding discard patterns of the European earthenwares to say much about the meaning of these artifacts to the inhabitants of the village. The finding of the abraded Isabela Polychrome sherd indicates the reuse or revaluing of this particular piece; in this artifact we see an outcome of transculturation and the coming together of cultural traditions.

The function of European earthenwares in indigenous sites like Playa Grande and El Cabo differs from the function of Amerindian ceramics in early Spanish towns. Within Amerindian settlements European earthenwares were regarded as items of high status. In Spanish towns local ceramics were brought in or made by Amerindian and African laborers, and were seen as utilitarian 
objects. The local manufacture of ceramics in Concepción de la Vega and Cotuí shows that the process of ceramic production is not as static as sometimes thought. Ceramics from the two Spanish colonial assemblages reveal that there are both continuities and changes in the manufacturing of ceramics in the early colonies. The forming of vessels by coiling is still the most common practice. However, the excavated potter's wheel from Concepción de la Vega and the presence of non-European wheel-finished ceramics show that wheel-made pottery was introduced to the colonies. Pastes, wall thicknesses, and specific vessel shapes from both sites correspond with precolonial ceramics. Continuity in the presence of Chicoid ceramics in Concepción de la Vega was more common than in Cotuí. However, new vessel shapes and decorative modes were introduced in both places, resembling Spanish, African, and Caribbean precolonial traditions. The assemblages of Cotuí and Concepción de la Vega reflect a process of transculturation in the chaine opératoire of the ceramic repertoire, whereby multiple traditions came together in the creation of a new material set. Continuities and changes in the production of ceramics in the colonies provide insight into the formal processes of colonization and the inter-cultural dynamics that occurred. Although laborers, captives, and enslaved people often lived marginal lives in the colonies, their role in the transculturation process is evident in the ceramic assemblages. Caribbean, African, and Spanish influences are reflected in the transcultural ceramics. The evidence of these cultural groups' influences on ceramic manufacturing is the first visible indicator of Caribbean-Spanish-African congruence in Spanish towns. The presence of Spanish vessel shapes made with local techniques may reflect the intention of maintaining the Iberian lifestyle in the colonies, also evidenced by the presence of the potter's wheel. The decline in Amerindian decorative forms may be ascribed to the effects of Spanish domination, including Christianization and labor obligations. At the same time, the assemblages show that the Spanish did not fully reinforce Iberian life. Some of the locally made ceramics were used as utilitarian vessels (Pagán-Jiménez 2012). Local cuisine is a pivotal marker denoting social and cultural identity (Beaudry 2013; Hofman et al. 2018; Mintz and Price 1985; Rodríguez-Alegría 2005). Amerindian and African influences in the making of cooking vessels reveal some form of cultural preservation among the enslaved at least in the less visible spaces of colonial society. It is here that indigenous as well as African ceramic cultural aspects were maintained by the people who made and used them.

Both the incorporation of European earthenwares in the indigenous settlements and the transcultural ceramics present at Spanish colonial sites have shown that the outcomes of the first encounters between indigenous peoples 
of Hispaniola, Spanish colonizers, and in some cases African enslaved peoples, differed greatly. The exchanges of ceramics and ceramic technologies occurred on various levels in differing contexts. The ceramic materials presented in this chapter show us that the intensity of contact was one of the most important factors for why and how the material implications of these communities in contact differ from case to case. They reveal cases of incorporation as well as cultural preservation, of maintaining social memory, and of expressing social agency in the diverse intercultural situations in early colonial Hispaniola.

\section{Acknowledgments}

The research leading to these results has received funding from the European Research Council under the European Union's Seventh Framework Programme (FP $7 / 2007-2013) / E R C-N E X U S 1492$ grant agreement no. 319209. We thank the Ministerio de la Cultura in Santo Domingo, the Museo del Hombre Dominicano, Adolfo López Belando, and the Oficina de Patrimonio Monumental for granting us permission to study the materials from El Cabo, Playa Grande, Concepción de la Vega and Cotuí, respectively. We are grateful to Jorge Ulloa, an anonymous reviewer, and Peter Siegel for their editorial comments.

\section{References}

Anderson-Córdova, Karen F. 1990. Hispaniola and Puerto Rico: Indian Acculturation and Heterogeneity 1492-1550. Ann Arbor: University Microfilms.

Anderson-Córdova, Karen F. 2017. Surviving Spanish Conquest. Indian Fight, Flight, and Cultural Transformation in Hispaniola and Puerto Rico. Alabama: University of Alabama Press.

Balfet, Hélène. 1984. "Methods of Formation and the Shape of Pottery." In The Many Dimensions of Pottery, Ceramics in Archaeology and Anthropology, edited by Sander van der Leeuw and Alison Pritchard, 171-202. Amsterdam: University of Amsterdam.

Bar-Yosef, Ofer and Philip van Peer. 20og. "The Chaine Operatoire Approach in Middle Paleolithic Archaeology." Current Anthropology 50 (1): 103-131.

Beaudry, Mary C. 2013. "Mixing Food, Mixing Cultures: Archaeological Perspectives." Archaeological review from Cambridge 28 (1): 285-297.

Bhabha, Homi K. 1994. The Location of Culture. London and New York: Routledge.

Card, Jebb J. 2007. The Ceramics of Colonial Ciudad Vieja, El Salvador: Culture Contact and Social Change in Mesoamerica. Tulane: Tulane University. 
Cohen, Jeremy. 1997. Preliminary Report on the 1996 Field Season at Concepción de la Vega. Project report submitted to the Dirección Nacional de Parques. Gainesville: Florida Museum of Natural History.

Deagan, Kathleen A. 1987. Artifacts of the Spanish Colonies of Florida and the Caribbean, 1500-1800, vol. 1: Ceramics, Glassware, and Beads. Washington, D.C.: Smithsonian Institution Press.

Deagan, Kathleen A. 1988. "The Archaeology of the Spanish Contact Period in the Caribbean." Journal of World Prehistory 2 (2): 187-233.

Deagan, Kathleen A. 1996. "Colonial Transformation: Euro-American Cultural Genesis in the Early Spanish-American Colonies." Journal of Anthropological Research $5^{2}$ (2): 135-160.

Deagan, Kathleen A. 1998. "Transculturation and Spanish American Ethnogenesis: The Archaeological Legacy of the Quincentenary." In Studies in Culture Contact: Interaction, Culture Change, and Archaeology, Occasional Paper Vol. 25, edited by James G. Cusick, 23-43. Carbondale: Center for Archaeological Investigations, Southern Illinois University.

Deagan, Kathleen A. 2002. Artifacts of the Spanish Colonies of Florida and the Caribbean, 1500-180o, vol.2: Portable Personal Possessions. Washington D.C.: Smithsonian Institution Press.

Deagan, Kathleen A. 2004. "Reconsidering Taino Social Dynamics after Spanish Conquest: Gender and Class in Culture Contact Studies." American Antiquity 69 (4): 597-626.

Deagan, Kathleen A. and Joseph M. Cruxent. 2002. Archaeology at La Isabela: America's First European Town. New Haven: Yale University Press.

DeCorse, Christopher R. and Mark W. Hauser. 2003. "Low-Fired Earthenwares in the African Diaspora: Problems and Prospects." International Journal of Historical Archaeology 7: 67-98.

Dommelen, Peter van. 1997. "Colonial constructs: colonialism and archaeology in the Mediterranean." World Archaeology 28 (3): 305-323.

Eliot, Charles W. 2001. American Historical Documents, 1000-1904, Vol XLIII. New York: P. F. Collier and Son.

Ernst, Marlieke. 2016. “(Ex)Changing the Potter's Process: Continuity and Change in the Non-European Ceramics of Cotuí, the First Colonial Mine in Hispaniola, after 1505." Research Master thesis, Leiden University.

Ernst, Marlieke and Corinne L. Hofman. 2015. "Shifting Values: A Study of Early European Trade Wares in the Amerindian Site of El Cabo, Eastern Dominican Republic." In GlobalPottery 1. Historical Archaeology and Archaeometry for Societies in Contact, edited by Jaime Buxeda i Garrigós, Marisol Madrid i Fernández, and Javier G. Iñañez, 195-204. Oxford: British Archaeological Reports, International Series 2761. 
Farbstein, Rebecca. 2011. "Technologies of Art: A Critical Reassessment of Pavlovian Art and Society, Using Chaîne Opératoire Method and Theory." Current Anthropology Vol. $5^{2}(3):$ 401-432.

Fontijn, David. 2002. Sacrificial landscapes: cultural biographies of persons, objects and 'natural' places in the Bronze Age of the southern Netherlands, c. 2300-6oo BC. Leiden: Sidestone Press.

French, Neal. 2005. Ceramics shapes and glazing guide. Kerkdriel: Librero.

Giddens, Anthony. 1979. Central Problems in Social Theory. London: Macmillan.

Goggin, John M. 196o. The Spanish Olive Jar: An Introductory Study, Yale University Publications in Anthropology Vol. 62. New Haven: Department of Anthropology, Yale University.

Gosden, Chris. 2006. “Material culture and long-term change.” In Handbook of Material Culture, edited by Chris Tilley, Webb Keane, Susanne Küchler, Mike Rowlands, and Patricia Spyer, 24-42. London: Sage Publications.

Gosselain, Olivier G. 2000. "Materializing identities: an African perspective." Journal of Archaeological Method and Theory 7 (3): 187-217.

Hannerz, Ulf. 1987. "The World in Creolization." Africa 57 (4):546-559.

Hernández Sánchez, Gilda. 2011. Ceramics and the Spanish Conquest, Response and Continuity of Indigenous Pottery Technology in Central Mexico. Leiden: Brill.

Hofman, Corinne L. 1993. In Search of the Native Population of Pre-Columbian Saba (400-1450 A.D.). Part One: Pottery Styles and their Interpretations. PhD diss., Leiden University.

Hofman, Corinne L., Menno L.P. Hoogland, and Alice V.M. Samson. 2008. "Investigaciones arqueológicos en El Cabo, oriente de la República Dominicana: resultados preliminares de las campañas 2005 y 2006." Boletín del Museo del Hombre Dominicano 35 (42): 307-316.

Hofman, Corinne L., Angus A.A. Mol, Menno L.P. Hoogland, and Roberto Valcárcel Rojas. 2014. "Stage of Encounters: migration, mobility and interaction in the precolonial and early colonial Caribbean." World Archaeology 46 (4): 591-6o9.

Hofman, Corinne L., Jorge Ulloa Hung, Eduardo Herrera Malatesta, Joseph Sony Jean, and Menno L.P. Hoogland. 2018. "Indigenous Caribbean Perspectives: Archaeologies and legacies of the first colonized region in the New World." Antiquity 92 (361): 200-216.

Hoskins, Janet. 2006. "Agency, biography and objects." In Handbook of Material Culture, edited by Chris Tilley, Webb Keane, Susanne Küchler, Mike Rowlands, and Patricia Spyer, 74-84. London: Sage Publications.

Knight, Vernon J. 2010. "La Loma del Convento: Its centrality to current issues in Cuban archaeology." In Beyond the Blockade: New Currents in Cuban Archaeology, edited by Susan Kepecs, L. Antonio Curet, and Gabino La Rosa Corzo, 26-46. Tuscaloosa: University of Alabama Press. 
Knippenberg, Sebastiaan. 2012. "Jadeitite axe manufacture in Hispaniola. A preliminary report on the lithics from the Playa Grande site, Northern Dominican Republic." In El sitio arquelógico de Playa Grande Río San Juan, María Trinidad Sánchez, informe de las excavaciones arquelógicas campaña 2011-2012, edited by Adolfo J. López Belando. Santo Domingo: Museo del Hombre Dominicano.

Kulstad, Pauline M. 2008. Concepción de la Vega 1495-1564: A Preliminary Look at Lifeways in the Americas' First Boom Town. Master thesis, University of Florida.

Las Casas, Bartolome de. (1527) 1974. Historia de las Indias. vol I, II and III. Santo Domingo: Editora Corripio, Sociedad Dominicana de Bibliófilos.

Leeuw, Sander E. van der. 1993. "Giving the potter a choice. Conceptual aspects of pottery techniques." In Technological choices: transformation in material cultures since the Neolithic, edited by Pierre Lemonnier, 23-28. London: Routledge.

Lemmonier, Pierre. 1986. "The study of material culture today: An anthropology of technical systems." Journal of Anthropological Archaeology 5 (2):147-186.

Lemmonier, Pierre. 1992. Elements for an Anthropology of Technology. Anthropological Papers No. 88. Ann Arbor: Museum of Anthropology, University of Michigan.

Lemmonier, Pierre. 2002. Transformation in material culture since the Neolithic. London: Routledge.

Leroi-Gourhan, André. 1964. La gueste et la parole. Paris: French ministry of culture. Translated by Anna Bostok Berger in 1993. Massachusetts: Massachusetts Institute of Technology.

Löbert, Horst W. 1984. "Types of Potter's Wheels and the Spread of the Spindle-Wheel in Germany." In The Many Dimensions of Pottery: Ceramics in Archaeology and Anthropology, edited by Sander E. van der Leeuw, 202-230. Amsterdam: Van Giffen Instituut voor Pre-en Protohistorie.

López Belando, Adolfo J. 2012. El sitio arquelógico de Playa Grande Río San Juan, María Trinidad Sánchez, informe de las excavaciones arquelógicas camaña 2011-2012. Excavation report. Santo Domingo: Museo del Hombre Dominicano.

López Belando, Adolfo J. 2013. "Excavaciones arqueológicas en el poblado taíno de Playa Grande, República Dominicana." In Proceedings of the 25th Congress of the International Association for Caribbean Archeology, edited by Laura Del Olmo, 254-280. San Juan: Instituto de Cultura Puertorriqueña, el Centro de Estudios Avanzados de Puerto Rico y el Caribe, y la Universidad de Puerto Rico, Recinto de Río Piedras.

Mártir Angleria, Pedro. 1964. Décadas del Nuevo Mundo 1. México DF: José Porrua e Hijos.

Mintz, Sidney W., and Sally Price. 1985. Caribbean Contours. Baltimore: Johns Hopkins University Press.

Moya-Pons, Frank. 1978. La Española en el siglo XVI. Santiago: Universidad Católica Madre y Maestra.

Nielsen, Axel. 1991. "Trampling the archaeological record: An experimental study." American Antiquity $5^{6}$ (3): 483-508. 
Ogundiran, Akinwumi. 2007. "Living in the Shadow of the Atlantic World: History and Material Life in a Yoruba-Edo Hinterland, ca. 1600-1750." In Archaeology of Atlantic Africa and the African diaspora, edited by Akinwumi Ogundiran and Toyin Falola, 77-99. Bloomington: Indian University Press.

Olsen Bogaert, Harrold G. 2004. "Sitio Arqueológico Playa Grande, Río San Juan, Provincia María Trinidad Sánchez." Boletín del Museo del Hombre Dominicano 37: 126-142.

Olsen Bogaert, Harrold G., Jorge Ulloa Hung, Victor Avila, and Frank Coste. 2011 . Pueblo Viejo Dominicana Corporation, Projecto Pueblo Viejo. Sitio Arqueológico No. 11 Investigación Estructuras Coloniales. Unpublished excavation report, on file at the Faculty of Archaeology, Leiden University.

Olsen Bogaert, Harrold G., Jorge Ulloa Hung, Victor Avila, and Frank Coste. 2011b. Pueblo Viejo Dominicana Corporation, Projecto Pueblo Viejo, Sitio Arqueológico No. $112 \mathrm{da}$ fase de investigación. Excavation report. Santo Domingo: Unpublished excavation report, on file at the Faculty of Archaeology, Leiden University.

Ortega, Elpidio and Carmen Fondeur. 1978. Estudio de la Cerámica del Período IndoHispánico de la Antigua Concepción de La Vega. Santo Domingo: Taller.

Ortiz, Fernando. (1940) 1995. Cuban Counterpoint: Tobacco and Sugar. Translated by Harriet de Onís. Durham: Duke University Press. Originally published in Spanish in 1940, Havana: Editorial de Ciencias Sociales.

Orton, Clive, Paul Tyers, and Alan Vince. 2005. Pottery in Archaeology. Cambridge: Cambridge University Press.

O'Shepard, Anna. 1963. Ceramics for Archaeologists. Washington DC: Carnegie institution of Washington.

Pagán-Jiménez, Jaime R. 2012. Almidones antiguos recuperados en artefactos cerámicos atribuidos a la fase de cantacto indohispánica del Sito 11, Pueblo Viejo, república Dominicana. Leiden: Internal report Leiden, Faculty of Archaeology.

Rice, Prudence M. 1984. "Change and Conservatism in Pottery-Producing Systems." In The Many Dimensions of Pottery: Ceramics in Archaeology and Anthropology, edited by Sander E. van der Leeuw, 231-293. Amsterdam: Van Giffen Instituut voor Pre-en Protohistorie.

Rice, Prudence M. 1987. Pottery Analysis, A source book. Chicago: University of Chicago Press.

Rivera-Pagán, Luis N. 2003. "Freedom and Servitude: Indigenous Slavery and the Spanish Conquest of the Caribbean." In General History of the Caribbean Vol. 1: Autochthonous societies, edited by Jalil Sued Badillo, 316-362. Paris: UNESCO Publishing.

Rodríguez-Alegría, Enrique. 2005. "Eating Like an Indian: Negotiating Social Relations in the Spanish Colonies." Current Anthropology 46 (4): 551-573.

Roe, Peter G. and Hernan Ortíz Montañez. 2014. "Small vessels, precious contents: miniature pots and ceramic discs from the Punta Mameyes site (DO-42), Dorado, Puerto Rico." Proceedings of the 24th Congress of the International Association for 
Caribbean Archeology, edited by Benoit Bérard, 300-336. Martinique: Université des Antilles et de la Guyane.

Rouse, Irving. 1992. The Taínos: Rise and Decline of the People who Greeted Columbus. New Haven: Yale University Press.

Roux, Valentine. 2016. "Ceramic Manufacture: The Chaîne Opératoire Approach." In The Oxford Handbook of Archaeological Ceramic Analysis, edited by Alice M.W. Hunt, 101-113. Oxford: Oxford University Press.

Samson, Alice V.M. 2010. Renewing the House: Trajectories of social life in the yucayeque (community) of El Cabo, Higüey, Dominican Republic, AD 800 to 1504. Leiden: Sidestone Press.

Sauer, Carl O. 1966. The Early Spanish Main. Berkeley and Los Angeles: University of California Press.

Schiffer, Michael B. 1983. "Towards the identification of formation processes." American Antiquity 48 (4): 675-706.

Schreg, Rainer. 2010. "Panamanian coarse handmade earthenware - a melting pot of African, American and European traditions?" Post-medieval Archaeology 44 (1): $135^{-164 .}$

Shephard, Herschel. 1997. A Report: The Fort at Concepción de la Vega, Dominican Republic and Standards, Interpretation and Conservation. Consultant report, submitted to the Dirección Nacional de Parques, Santo Domingo, and U.S.A.I.D. Gainesville: Florida Museum of Natural History.

Skibo, James M. and Micheal B. Schiffer 2008. People and Things. A Behavioural Approach to Material Culture. New York: Springer.

Sued Badillo, Jalil. 2001. El Dorado Borincano: La Economía de la Conquista 1510-1550. San Juan: Ediciones Puerto.

Sudbury, Byron, J. and Ellen Gerth. 2014. "Clay Tobacco Pipes from the Tortugas Shipwreck, Florida (1622)." Odyssey Papers 41: 1-15.

Ting, Carmen, Jorge Ulloa Hung, Corinne L. Hofman, and Patrick Degryse. 2018. "Indigenous Technologies and the Production of Early Colonial Ceramics in Dominican Republic." Journal of Archaeological Science: Reports 17: 47-57.

Torres, Joshua M. and Lisbeth A. Carlson. 2014. "Spindle whorls and fiber production: evidence from two Late Ceramic Age sites in eastern Puerto Rico." In Proceedings of the 24th Congress of the International Association for Caribbean Archeology, edited by Benoit Bérard, 180-188. Martinique: Université des Antilles et de la Guyane.

Valcárcel Rojas, Roberto. 2012. "Interacción colonial en un Pueblo de indios encomendados, El chorro de Maita. Cuba." PhD diss., Leiden University.

Valcárcel Rojas, Roberto, Alice V.M. Samson, and Menno L.P. Hoogland. 2013. "IndoHispanic Dynamics: From Contact to Colonial Interaction in the Greater Antilles." International Journal of Historical Archaeology 17 (1): 18-39. 
Veloz Maggiolo, Marcio and Elpidio Ortega. 1980. "Nuevos Hallazgos Arqueológicos en la Costa Norte de Santo Domingo." Boletín del Museo del Hombre Dominicano 13: 11-48.

Voss, Barbara L. 2008. The Archaeology of Ethnogenesis: Race and Sexuality in Colonial San Francisco. Berkeley and Los Angeles: University of California Press.

Weaver, Brendan J.M. 2015. "Fruit of the vine, work of human hands": An Archaeology and Ethnohistory of Slavery on the Jesuit Wine Haciendas of Nasca, Peru. PhD diss., Vanderbilt University. 